演題 47 ，超音波診断装置の断買厚さを各深さにおける 半值幅として求めた報告である。測定方法て苦心された ようだが, 超音波診断装置の性能の測定法，評価につい て今後の研究に期待する.

コンピュータ応用

座長：近藤隆司（宮崎医大）

48. パソコンを応用したセット・トーーズタイム)の計算 熊本大学医学部附属病院中块放射線部

○守部伸幸・田上昭一

樺島祥平・平田幸徳

[目的]放射線治蟟時のモ二タ線量計のセットドーズ およびセットタイムを治療パラメータを入力するだけで 求まるようにし，その結果をプリンタでプリントしたむ のを, カルテに粘付し，業務の煩雑さの解消を行う。

[方法]データ検索システムと，マトリックス計算法 により目的とする field およひ depth での TPR を求め t:

[結果]実測值乞ほとんじ変わらず, 煩雑さの解消, および計算者しよってのバラッキゃミスが皆無しなり， 迅速化ができた。

49. フィルムーレポート管理システムについて 九州大学医学部附属病院放射線部 ○中村泰彦

X線写真の保存・管理は，放射線部門における重要な 業務であることは言うまであない。

そこで, 特に術前後の比較や経過観察の頻度が高い一 般造影部門 (腎皿造影・胆のう胆管造影検查)ではX線 写真のコピーと診断レポートを保管している. との部門 に省力化・能率向上を目的にマイクロコンピュータとカ ルテ検索機を利用しだX線写真を診断レポート管理・自 動铪索システムを設置したので紹介する。

〔ま亡め] (1)多種の項目から検索可能で瞬時に取り出 せる. (2)悵簿類の廃止などによって，事務的な業務の省 力化ができる,

\section{0. マイコン制御装置による撮影条件の検討}

社会保険宮崎江南病院放射線室

○恒吉徳隆・橋元腪人 広烟盛雄・黑木和則

島津製一般撮影装置 SHD150Gは，マイコンを忘用し， 撮影条件の作製を可能にしている。撮影条件の作製に際 しては, Dose step (被写体厚 $1 \mathrm{~cm}$ の変化に対する総線 量の変化率) と, MAS step (総線量の変化䎲占める $\mathrm{mAs}$ の変化率) が，基準撮影条件に係数として与えられねば ならない。実験において各撮影部位に刘する基準撮影条 件 $(\mathrm{kV}, \mathrm{mAs})$ を設定し，その時の Dose step を決定す
るととを試みた。 Dose step法まれば MAS stepは条 件表の夕イプによて決まる. 求められたDose step は臨 床上では，若千の補正を必要としたが大差はなく，臨床 にも良い結果を得ている。

\section{座長集約}

最近, コンピュータの技術開発が著しく,コンパクト 化，低コスト北によて，その利用範囲が急速に広がって きた。喰療業務においては，X線 CT, RI デー夕処理, 治療時線量分布計算などにコンピュータが導入されてお り, この演題群はその一例である。

コンピュータ利用の最太の利点は，多くのデータを短 時間に，正確に計算処理できるととである.とのため， 人間介在による種々のミスが減少し，演題 $48 ， 500$ 上う に，目的とするデータを容易に，再現性良く得るととが 可能となった。しかし，コンピュータも機械であって万 能ではなりので， あらゆる条件の下で計算結果を吟味し 目的に適合しているかどうかを常に確認しておかなくて はならない.

演題49は，事務的管理への応用であり，一般企業では 盛んであるが，放射線喨療データの管理べの応用はまだ まだ少ない。あっととの方向の応用を望みたい.

コンピュータがてれほじ急速に発展してきた理由は, ある一連の作業を人間が行なうことよりもコンピュータ が行なうととの方が利点が多いととを既て知っているか らである.乙こで強調しておきたいことは、コンピュー タをいか加利用していくかということである。また，コ ンピュータは、ソフトウェアがあってはじめて計算処理 が可能となるととは言うまでもないが，ソフトウェアは ほとんどがメーカサイドで作られたものである。しかし， その利用を容易かつ多様化するためには演題480ように ユーザサイドでソフトを開発してもらいたい，さらには， そのととによって研究面への応用に発展性がでてくるか らである. 今後の努力を期待したい.

\section{感光材料}

\section{座長 真野勇夫（健和総合病院）}

\section{1. 增感紙の検討 その1 胎児撮影} 福岡大学病院放射線診断部

○堀之内まゆみ・村中博伸・吉川治雄

胎児撮影におしてレギュラーフィルムを用いたまま， 増感紙の選択のみで診断を充分に満足でき，かつ，胎児 被暴をどれくらい減少できるかについて LT-II, REspecial, LU, Quanta III の 4 種の増感紙で検討した。 そ の結果，ブルー発光の希土類増感紙の出現により次のよ うなメリットがあるととがわかった。まず，管電圧を下 